\title{
An immunocytochemical study of malignant melanoma and its differential diagnosis from other malignant tumours
}

\author{
KC GATTER, * E RALFKIAER, † J SKINNER, † B BOWN,**A HERYET,* \\ KAF PULFORD, ${ }^{*}$ K HOU-JENSEN, $†$ DY MASON* \\ From the *Nuffield Department of Pathology, John Radcliffe Hospital, Oxford, the †Department of \\ Pathology, The Finsen Institute, Copenhagen, and the $\ddagger$ Department of Pathology, Flinders Medical Centre, \\ Adelaide, Australia
}

SUMMARY A series of 41 fresh and 36 routinely processed malignant melanomas were immunostained with a panel of 12 monoclonal antibodies reactive against a range of epithelial, lymphoid, and melanoma associated antigens. The aim of the study was to determine whether this panel of antibodies would be useful in diagnostically difficult cases for differentiating melanomas from other tumours, particularly carcinomas and lymphomas. The results confirmed that most unequivocal malignant melanomas can be identified by positivity for $\mathrm{S} 100$ protein and for the antigen recognised by antibody NK1/C3, and by negativity for epithelial and lymphoid antigens. The incidence of melanomas expressing cytokeratin antigens was higher, however, particularly in cryostat sections than has previously been reported. It is therefore suggested that a panel of antibodies with more than one marker in each category should be used for identifying melanomas in clinical practice.

When the origin of a malignant tumour is unknown the two most likely alternative diagnoses are lymphoma and carcinoma. Recently, studies performed in several laboratories have established the patterns of antigenic expression characteristic of these two categories of tumour, ${ }^{1-11}$ so that they can now almost always be diagnosed by immunohistological labelling with an appropriate panel of monoclonal antibodies. A few tumours of uncertain origin encountered in routine histopathological practice lack the antigen profile of either lymphoma or carcinoma: in our own experience these cases account for $10 \%-15 \%$ of anaplastic tumour biopsies.

Further investigation of such cases indicates that the most common diagnosis is melanoma, and several studies have suggested that immunocytochemical labelling may be of value for indentifying this type of tumour. ${ }^{12-16}$ There has been no comprehensive study of the immunophenotype of unequivocal malignant melanomas that would enable the reliability of this approach in practice to be assessed, however, and, in particular, it is not certain whether or not malignant

Accepted for publication 6 August 1985 melanomas may, on occasion, express the antigenic markers found on epithelial tumours.

In this study a large number of fresh and routinely processed malignant melanomas were examined with a panel of monoclonal antibodies against a wide range of epithelial, lymphoid, and other antigens. These results were compared with those from several other tumour types, including lung tumours, skin tumours, and a series of malignant tumours of uncertain histological origin. The results confirmed that it is now possible to add melanoma to the list of anaplastic tumours, which can be identified by immunocytochemical means, when difficulty arises in establishing a diagnosis on conventional grounds.

\section{Material and methods}

Fresh biopsies of various different tumours were received from patients attending either the John Radcliffe Hospital, Oxford or the Finsen Institute, Copenhagen, where most of the fresh melanomas were collected. A representative portion was removed from each biopsy for immunohistological examination, and the remainder was processed in the conventional manner by fixation in formalin and embedding in paraffin. The portion of unfixed tissue 

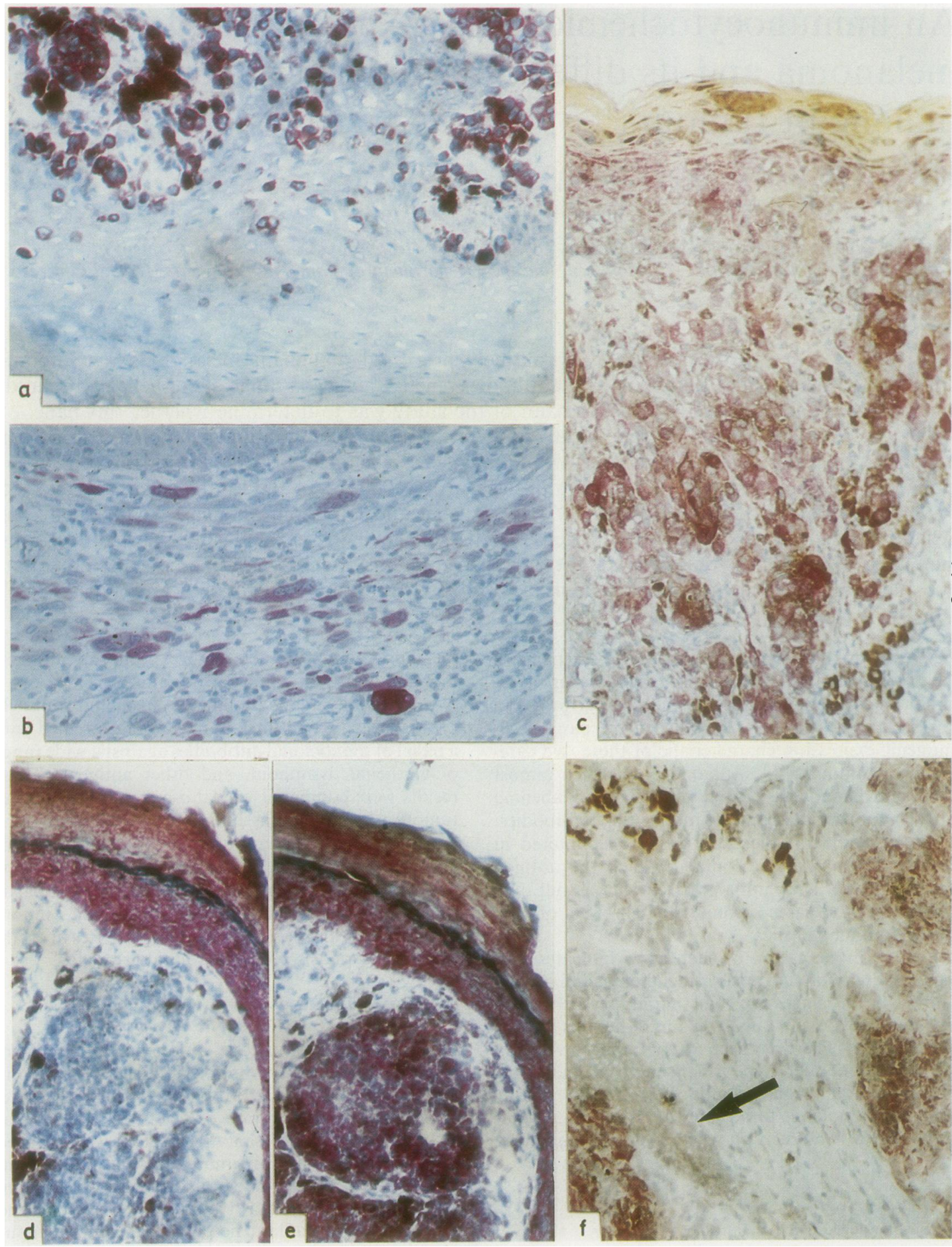
Fig. 1a Homogeneous staining of cutaneous malignant melanoma for melanoma associated antigen recognised by monoclonal antibody $N K 1 / C 3$.

$b$ and $c$ also show extensive staining for S100 protein in cutaneous malignant melanomas (antibody S1.61).

$d$ and $e$ are serial sections of nodular melanoma stained with two anticytokeratins, $K L I(D)$ and PKI10 (E). Note that

PK110 stains melanoma nodules strongly, in addition to overlying epidermis.

$f$ is nodular melanoma which reacts with anticytokeratin (CAM5.2) while overlying epidermis (arrow) is unstained. Note patches of brown melanin pigment (top left). Use of the APAAP immunoalkaline phosphatase technique is valuable when staining melanoma biopsies as it avoids problems of interpretation due to melanin pigment.

$b$ is routinely fixed paraffin embedded section. The rest are cryostat sections. All were stained by APAAP technique.

was immediately frozen in liquid nitrogen and stored at $-70^{\circ} \mathrm{C}$. Cryostat sections were collected on slides coated with gelatin, thoroughly air dried, and fixed for 10 minutes in cold acetone. Routinely processed paraffin blocks were retrieved from the files of the histopathology department, John Radcliffe Hospital, Oxford and the Flinders Medical Centre, Adelaide, where most of the routinely processed melanomas were obtained.

Table 1 gives details of the monoclonal antibodies used in this study. Sections were immunostained by a three stage immunoperoxidase procedure or the APAAP (alkaline phosphatase: antialkaline phosphatase) technique as described previously. ${ }^{1718}$ All the melanomas were stained by the APAAP technique to avoid the problem of distinguishing immunoperoxidase staining from melanin. Fifteen of the 41 frozen section melanomas were positive for HLA-DR. It was impossible to test routinely processed sections for the presence of this antigen as the anti-HLA-DR antibodies available for this study did not react reliably with tissues fixed in formalin.

Table 1 Details of monoclonal antibodies used in study

\section{Results}

Table 2 gives the results of immunostaining 41 fresh and 36 formalin fixed melanomas, together with the labelling reactions of a total of 120 other types of tumour (basal cell and squamous cell carcinoma of skin, carcinoma of the lung, poorly differentiated carcinoma, and lymphoma).

Most of the melanomas (in both paraffin and cryostat sections) showed strong positivity for the $\mathrm{NK} 1 / \mathrm{C} 3$ antigen and for the $\mathrm{S} 100$ protein, usually homogeneously distributed throughout the tumour (Figs. 1a-c). This contrasted with other tumour types in which the labelling was seen only in occasional biopsies and was usually much weaker than that in the melanomas. Only one routinely processed melanoma, failed to express either of these markers. This tumour did not stain with any of the other antibodies in the panel.

The melanomas also differed from other categories of tumour in that they were usually negative for cyto-

\begin{tabular}{lll}
\hline Antibody & $\begin{array}{l}\text { Antigen } \\
\text { Cytokeratins: }\end{array}$ & Reference \\
\hline KL1 & 55-57KD & 20 \\
CAM5.2 & 39-50KD & 14 \\
PK 52 & 64-67KD & K Pulford \\
PK 63 & $50-67 \mathrm{KD}$ & \\
PK 110 & $50-67 \mathrm{KD}$ & \\
PK 121 & $61-62 \mathrm{KD}$ & \\
PK 141 & 46-59KD & 21 \\
S1.61 & S100 protein & 21 \\
S3.77 & S100 protein & 22 \\
E29 & Epithelial membrane antigen (EMA) \\
NK1/C3 & Melanoma associated antigen & 16 \\
CR3/43 & HLA-DR & 23 \\
\hline
\end{tabular}

Table 2 Comparison of reactivity of melanoma and lung carcinoma on cryostat and routinely embedded tissue samples

\begin{tabular}{|c|c|c|c|c|c|c|c|c|c|c|c|}
\hline & \multirow[t]{2}{*}{ Material } & \multirow[t]{2}{*}{$\begin{array}{l}\text { No of } \\
\text { Cases }\end{array}$} & \multirow{2}{*}{$\begin{array}{l}\text { Melanoma } \\
\text { associated } \\
\text { antigen } \\
(N K I / C 3)\end{array}$} & \multirow{2}{*}{$\begin{array}{l}\text { S100 } \\
\text { protein }\end{array}$} & \multicolumn{5}{|c|}{ Cytokeratin } & \multicolumn{2}{|l|}{. } \\
\hline & & & & & $\overline{K L I}$ & CAM5.2 & $P K 110$ & $P K 121$ & $E M A$ & $C E A$ & $H L A-D R$ \\
\hline $\begin{array}{l}\text { Melanoma } \\
\text { Melanoma } \\
\text { Lung cancer } \\
\text { Lung cancer }\end{array}$ & $\begin{array}{l}\text { Cryostat } \\
\text { Routine } \\
\text { Cryostat } \\
\text { Routine }\end{array}$ & $\begin{array}{r}41 \\
36 \\
11 \\
7\end{array}$ & $\begin{array}{r}41 \\
31 \\
4 \\
1\end{array}$ & $\begin{array}{r}40 \\
31 \\
11 \\
4\end{array}$ & $\begin{array}{r}0 \\
0 \\
11 \\
7\end{array}$ & $\begin{array}{r}4 \\
0 \\
11 \\
7\end{array}$ & $\begin{array}{c}29 \\
4 \\
\text { ND } \\
3\end{array}$ & $\begin{array}{l}2 \\
1 \\
\text { ND } \\
2\end{array}$ & $\begin{array}{l}0 \\
0 \\
9 \\
7\end{array}$ & $\begin{array}{l}0 \\
0 \\
5 \\
5\end{array}$ & $\begin{array}{l}15 \\
\text { ND } \\
4 \\
\text { ND }\end{array}$ \\
\hline
\end{tabular}

Anticytokeratin antibodies PK 52, PK 63, and PK 141 were negative with all melanomas and positive (to different degrees) with epithelial tumours. 
Table 3 Comparison of reactivity of routinely processed melanomas and other tumour types

\begin{tabular}{|c|c|c|c|c|c|c|c|c|c|}
\hline & \multirow{2}{*}{$\begin{array}{l}\text { No of } \\
\text { cases }\end{array}$} & \multirow{2}{*}{$\begin{array}{l}\text { Melanoma } \\
\text { associated } \\
\text { antigen } \\
(N K I / C 3)\end{array}$} & \multirow{2}{*}{$\begin{array}{l}\text { S100 } \\
\text { protein }\end{array}$} & \multicolumn{6}{|c|}{ Cytokeratins } \\
\hline & & & & $\overline{K L I}$ & $C A M 5.2$ & PKII0 & $P K 121$ & $E M A$ & $C E A$ \\
\hline Melanoma & 36 & 31 & 31 & 0 & 0 & 4 & 1 & 0 & 0 \\
\hline Lung cancer & 7 & 1 & 4 & 7 & 7 & 3 & 2 & 7 & 5 \\
\hline Skin, squamous cell carcinoma & 16 & 0 & 7 & 11 & 1 & 7 & 12 & 12 & 2 \\
\hline Skin, basal cell carcinoma & 11 & 0 & 3 & 5 & 1 & 1 & 5 & 0 & 0 \\
\hline \multicolumn{10}{|l|}{ Anaplastic tumours } \\
\hline Carcinomas & 20 & 4 & 9 & 19 & 19 & ND & ND & 19 & 6 \\
\hline Lymphomas & 55 & 6 & 11 & 0 & 0 & ND & ND & 0 & 0 \\
\hline
\end{tabular}

Anticytokeratin antibodies PK 52, PK 63, and PK 141 were negative with all melanomas and positive (to different degrees) with epithelial tumours.

keratins (Fig. 1d) and other epithelial markers (epithelial membrane antigen and carcinoembryonic antigen). All the carcinomas were positive for many or all of these. Twenty nine of 41 frozen and four of 36 routinely processed melanomas, however, were positive with the anticytokeratin PK 110 (recognising cytokeratins of 50-67 kilodaltons molecular weight) (Fig. 1e). In addition, occasional melanomas were stained by two other anticytokeratin antibodies, positive staining being seen with PK121 and CAM 5.2 (Fig. 1f). Each of the melanomas that reacted with one or more of the anticytokeratin antibodies showed typical staining for $\mathrm{S} 100$ protein or NK1/C3.

\section{Discussion}

Recently the differential diagnosis of anaplastic malignant tumours has been considerably facilitated by the introduction of immunohistological labelling with monoclonal antibodies against epithelial, lymphoid, and other antigens. Many of these antibodies react only with acetone fixed cryostat sections prepared from fresh biopsy material. As many diagnostic problems are appreciated by the pathologist only after a tissue biopsy has undergone fixation in formalin and processing the application of this approach in routine diagnosis was initially limited. The recent production of a small number of monoclonal antibodies against epithelial, lymphoid, and other antigens, which are suitable for use on routine paraffin embedded material, has extended the use of these techniques into the routine diagnostic laboratory.

Several studies have shown that a major problem in general pathological practice is the distinction between carcinoma and lymphoma. The monoclonal reagents now available against epithelial and lymphoid antigens enable most of these cases to be identified. ${ }^{4610119}$ Amelanotic malignant melanoma, however (traditionally one of the most important differential diagnoses), is recognised only by lack of immunostaining for these markers or by positivity for antigens shared by many other tumours-for $\vec{N}$ example, vimentin.

In previous immunocytochemical studies either a of series of melanomas was analysed with a single antibody or a few cases of melanoma were included in a large series of anaplastic tumours. The picture that emerged from these studies was that melanoma can be reliably identified by a combination of negativity for epithelial and lymphoid antigens and positivity for $\frac{}{0}$ S100 protein and antigens associated with $\stackrel{\Phi}{-}$ melanoma-for example, that recognised by antibod $\overrightarrow{0}$ NK1/C3.121516

This study investigated the practical utility immunocytochemistry in diagnosing melanoma bo staining a large series of melanomas, both in cryostat and routinely processed sections, with a panel of 12 different monoclonal antibodies. These results were $\frac{2}{\Phi}$ compared with the patterns seen in lung carcinomas, $\stackrel{\varrho}{\rightarrow}$ squamous and basal cell carcinomas of skin, and in a series of 75 carcinomas and lymphomas that had been considered to be undiagnosable before immunocytochemical study.

These findings confirm that more than $85 \%$ of both cryostat and routinely processed sections of melanoma are positive with both NK1/C3 and anti-S100 antibodies. As in previous studies neither of these two markers was restricted to the presence of melanomas on a small number of carcinomas and lymphomas. 을

In contrast to their strong reactivity with antibody $>$ NK1/C3 and anti-S100, most melanomas were negative for epithelial associated antigens. It should be noted, however, that the incidence of melanomas. expressing these antigens may be higher than has been $\tilde{O}$ appreciated in the past. It is evident from this study that although the anticytokeratin antibody PK1100 stained only four out of 36 cases of melanoma in paraffin sections, it was reactive in more than $50 \%$ of cases $(29$ of 41$)$ when tested on cryostat sections. $\stackrel{?}{?}$ Hence the concept that melanomas usually lack epi- $\square$ thelial cytokeratins may indicate that many previous studies were performed on paraffin tissue sections in 
which a considerable loss of antigenic reactivity occurred.

The particular monoclonal antibody used to detect cytokeratins may also influence the occurrence of positive labelling. In this context it is of practical importance that we found that the monoclonal anticytokeratin antibody, CAM5.2, a reagent previously regarded as specific for epithelial tissues, ${ }^{14}$ labelled a few melanomas (four of 41) when tested on cryostat sections. This substantiates other observations of non-epithelial cell staining with this antibody in lymphoid tissue (unpublished observations). Whether these results mean that some melanomas contain cytokeratin intermediate filaments or that the antiepithelial antibodies recognise shared epitopes on different intermediate filaments is still unclear.

The results of this study allow the important practical conclusion to be drawn that malignant melanoma can often be identified by strong positivity for both $\mathrm{S} 100$ protein and for the antigen recognised by antibody NK $1 / \mathrm{C} 3$. In view of the occasional reaction of these antibodies with non-melanocytic tumours, however, we recommend that the panel of antibodies used for diagnosing melanoma should contain at least two antiepithelial antibodies. A suitable panel for this purpose should therefore consist of anti-S100, antibody $\mathrm{NK} 1 / \mathrm{C} 3$, three antiepithelial antibodies (two anticytokeratins and one antiepithelial membrane antigen), and an antileucocyte common antibody.

We thank Drs J Brochier, P Hageman, and C Makin for providing samples of $\mathrm{KL} 1, \mathrm{NK} 1 / \mathrm{C} 3$, and CAM5.2, respectively.

This study was supported by grants from the Leukaemia Research Fund, the Danish Cancer Society, and the Wellcome Trust. KCG holds the Gillson Scholarship of the Society of Apothecaries of London.

\section{References}

${ }^{1}$ Janossy G, Thomas JA, Pizzolo G, et al. Immunohistological diagnosis of lymphoproliferative diseases by selected combinations of antisera and monoclonal antibodies. $B r J$ Cancer 1980;42:224-42.

${ }^{2}$ Pizzolo G, Sloane J, Beverley P, et al. Differential diagnosis of malignant lymphoma and non-lymphoid tumours using monoclonal anti-leucocyte antibody. Cancer 1980;46:2640-7.

${ }^{3}$ Altmannsberger M, Osborn M, Schauer A, Weber K. Antibodies to different intermediate filament proteins: cell type-specific markers on paraffin-embedded human tissues. Lab Invest 1981;45:427-34.

${ }^{4}$ Gabbiani G, Kapanci Y, Barazzone P, Franke WW. Immunochemical identification of intermediate-sized filaments in human neoplastic cells. A diagnostic aid for the surgical pathologist. Am J Pathol 1981;104:206-16.
${ }^{5}$ Sloane JP, Ormerod MG. Distribution of epithelial membrane antigen in normal and neoplastic tissues and its value in diagnostic tumour pathology. Cancer 1981;47:1786-95.

${ }^{6}$ Gatter KC, Abdulaziz Z, Beverley P, et al. Use of monoclonal antibodies for the histopathological diagnosis of human malignancy. J Clin Pathol 1982;35:1253-67.

${ }^{7}$ Nagle RB, McDaniel KM, Clark VA, Payne CM. The use of antikeratin antibodies in the diagnosis of human neoplasms. Am J Clin Pathol 1983;79:458-66.

${ }^{8}$ Van Muijen GNP, Ruiter DJ, Ponec M, Huiskens-Van der Mey C, Warnaar SO. Monoclonal antibodies with different specificities against cytokeratins. An immunohistochemical study of normal tissue and tumors. Am J Pathol 1984;114:9-17.

${ }^{9}$ Debus E, Moll R, Franke WW, Weber K, Osborn M. Immunohistological distinction of human carcinomas by cytokeratin typing with monoclonal antibodies. Am J Pathol 1984;114:121-30.

${ }^{10}$ Gatter KC, Alcock C, Heryet A, et al. The differential diagnosis of routinely processed anaplastic tumours using monoclonal antibodies. Am J Clin Pathol 1984;82:33-43.

${ }^{11}$ Lauder I, Holland D, Mason DY, Gowland G, Cunliffe WJ. Identification of large cell undifferentiated tumours in lymph nodes using leucocyte common and keratin antibodies. Histopathology 1984;8:259-72.

${ }^{12}$ Nakajima T, Watanabe S, Sato Y, Kameya T, Shimosato Y, Ishihara K. Immunohistochemical demonstration of S100 protein in malignant melanoma and pigmented nevus, and its diagnostic application. Cancer 1982;50:912-8.

${ }^{13}$ Ramaekers FCS, Puts JJG, Moesker O, Kant A, et al. Intermediate filaments in malignant melanomas. J Clin Invest 1983;71:635-43.

${ }^{14}$ Makin CA, Bobrow LG, Bodmer WF. Monoclonal antibody to cytokeratin for use in routine histopathology. J Clin Pathol 1984;37:975-83.

${ }^{15}$ Van Duinen SG, Ruiter DJ, Hageman P, et al. Immunohistochemical and histochemical tools in the diagnosis of amelanotic melanoma. Cancer 1984;53:1566-73.

${ }^{16}$ Mackie RM, Campbell I, Turbitt M. Use of NK1/C3 monoclonal antibody in the assessment of benign and malignant melanocytic lesions. J Clin Pathol 1984;37:367-72.

${ }^{17}$ Gatter KC, Falini B, Mason DY. The use of monoclonal antibodies in histopathological diagnosis. Rec Adv Histopathol 1984;12:35-67.

${ }^{18}$ Cordell JL, Falini B, Erber WN, et al. Immunoenzymatic labeling of monoclonal antibodies using immune complexes of alkaline phosphatase and monoclonal anti-alkaline phosphatase (APAAP Complexes). J Histochem Cytochem 1984;32:219-29.

${ }^{19}$ Gatter KC, Alcock C, Heryet A, Mason DY. The clinical importance of analysing malignant tumours of uncertain origin by immunohistological techniques. Lancet 1985; ;:1302-5.

${ }^{20}$ Viac J, Reano A, Brochier J, Staquet M-J, Thivolet J. Reactivity pattern of a monoclonal antikeratin antibody (KL1). $J$ Invest Dermatol 1983;81:351-4.

${ }^{21}$ Vanstapel MJ, Peeters B, Cordell J, et al. Production and identification of monoclonal antibodies directed against an antigenic determinant common to the alpha and beta chain of $\$ 100$. Lab Invest 1985;52:232-8.

${ }^{22}$ Delsol G, Gatter KC, Stein H, et al. Human lymphoid cells may express epithelial membrane antigens: Implications for the diagnosis of human neoplasms. Lancet 1984;ii:1124-9.

${ }^{23}$ Gatter KC, Pulford KAF, Vanstapel MJ, et al. An immunohistological study of benign and malignant skin tumours: epithelial aspects. Histopathology 1984;8:209-27.

Requests for reprints to: Dr KC Gatter, Nuffield Department of Pathology, John Radcliffe Hospital, Oxford OX3 9DU, England. 